\title{
Gut function and dysfunction in young pigs: physiology
}

\author{
Jean-Paul LALLÈS ${ }^{\mathrm{a} *}$, Gaëlle BOUDRY ${ }^{\mathrm{a}}$, Christine FAVIER ${ }^{\mathrm{a}}$, \\ Nathalie LE FLOC' $\mathrm{H}^{\mathrm{a}}$, Isabelle LURON ${ }^{\mathrm{a}}$, Lucile MONTAGNE ${ }^{\mathrm{a}}$, \\ Isabelle P. OswALD ${ }^{\mathrm{b}}$, Sandrine PIÉb ${ }^{\mathrm{b}}$, Christelle PIEL ${ }^{\mathrm{a}}$, Bernard SÈVE \\ a Institut National de la Recherche Agronomique, UMRVP INRA-ENSAR, Domaine de la Prise, \\ 35590 Saint-Gilles, France \\ b Institut National de la Recherche Agronomique, INRA Pharmacologie-Toxicologie, BP 3, \\ 31931 Toulouse Cedex 9, France
}

(Received 5 January 2004; accepted 27 May 2004)

\begin{abstract}
The post-weaning period in pigs is characterized by an immediate but transient drop in feed intake resulting in severe undernutrition and growth check. This in turn affects various aspects of small intestinal architecture and function leading to gut-associated disorders and often diarrhea. Among these, villus atrophy and digestive enzyme activity depression have been documented. More recent investigations clearly demonstrate early signs of local inflammation including immune cell infiltration and increased pro-inflammatory cytokine gene expression, signs of cytoprotection through up-regulation of so-called heat shock proteins, indications of tissue alterations by proteases (stromelysin) and finally epithelial functional disorders in mineral absorption/secretion and permeability. This is followed by a regenerative phase, probably stimulated by feed intake resumption, resulting in down-regulation of many intestinal indicators. However, some of them then display new spatio-temporal adult-type adaptive patterns of maturation. A limited number of substances, particularly nitrogenous compounds and complex preparations of animal origin (colostrum, plasma) have proven to be successful, at least partly, in minimizing post-weaning intestinal disturbances. Thus further research in intestinal physiology, in association with microbiology and immunology, is warranted to strengthen our understanding of the mechanisms of gut disorders in order to provide a better rational basis for designing suitable alternatives to in-feed antibiotics for pigs.
\end{abstract}

\section{intestine / nutrition / pathophysiology / pig / weaning}

Résumé - Fonctionnement normal et perturbé du tube digestif du jeune porcelet : physiologie. La période post-sevrage est caractérisée, chez le porcelet, par une réduction immédiate mais transitoire de la consommation d'aliment, conduisant à un état de sous-nutrition sévère et d'arrêt de croissance. Ceci affecte divers aspects de l'architecture et des fonctions de l'intestin grêle générant des troubles digestifs, voire des diarrhées. Parmi ceux-ci, l'atrophie villositaire et la dépression des activités enzymatiques digestives ont souvent été rapportées. Des recherches plus récentes ont

* Corresponding author: lalles@ rennes.inra.fr 
clairement montré des signes précoces d'inflammation incluant une infiltration cellulaire et l'expression accrue des gènes de plusieurs cytokines inflammatoires, une cytoprotection renforcée par la sur-expression des protéines du choc thermique, des indications d'altérations tissulaires par des protéases (stromélysines), et finalement des désordres fonctionnels épithéliaux d'absorption et de sécrétion minérales et de la perméabilité intestinale. Ceci est suivi par une phase de régénération intestinale, probablement stimulée par la reprise de consommation alimentaire, et conduisant à un retour à la normale de plusieurs indicateurs. Cependant, certains d'entre eux ont évolué vers des profils spatio-temporels adaptatifs de type adulte. Un nombre limité de substances, particulièrement des composés azotés et des produits animaux (colostrum, plasma) ont démontré leur capacité, au moins partielle, à minimiser les perturbations digestives post-sevrage. De nouvelles recherches en physiologie digestive, en association avec la microbiologie et l'immunologie, sont nécessaires pour renforcer notre compréhension des mécanismes des troubles digestifs. Ceci permettra de fournir des bases plus rationnelles pour développer des solutions alternatives satisfaisantes aux antibiotiques dans les aliments pour porcelets.

\section{intestin / nutrition / physiopathologie / porcelet / sevrage}

\section{INTRODUCTION}

Weaning is a major critical period of pig rearing because of increased susceptibility to gut disorders, infections and diarrhea. Over the last decades, the management of this so-called post-weaning (PW) diarrhea syndrome has involved the preventive use of antibiotics and metals (copper and zinc) in weaner diets. However, increased bacterial resistance to antibiotics and environmental problems caused by metals has led the European Union to consider a full ban on in-feed antibiotics by the 1st of January 2006 and a drastic reduction in the levels of incorporation of copper and zinc. These policy changes have prompted the feed industry to propose alternative substances to control PW disorders. Although some alternatives are effective, many others have not yet convinced. Thus, it appears that the detailed mechanisms of intestinal structural and functional alterations first need to be better understood to sustain a rational development of new alternatives and dietary strategies.

Weaning involves complex psychological, social, environmental and dietary stresses that interfere with gut development and adaptation (Tab. I). The immediate effect of weaning is a dramatic reduction in feed (energy) intake leading to undernutrition and a transient growth check. Although the first PW meal is usually consumed within $24 \mathrm{~h}$ PW in $50 \%$ of the piglets, it has not taken place until $48 \mathrm{~h}$ in $10 \%$ [7]. Thus, the newly weaned pig needs $3 \mathrm{~d}$ PW to meet energy requirements for maintenance and 8 to $14 \mathrm{~d}$ for recovery to the preweaning level of energy intake [39]. Intestinal alterations often seen PW in piglets include changes in villus/crypt morphology and in brush border enzyme activities, and implication of enteric pathogens (Escherichia coli and rotaviruses) have also been addressed [65]. Intestinal tissue damage was initially thought to be due to immune-mediated hypersensitivity reactions (reviews by $[17,37,76]$ ). More recently, it was hypothesized that immediate anorexia PW was a primary aetiological factor [50]. This review presents the most recent developments in the understanding of PW disorders and some solutions for improvements.

\section{WEANING AND THE INTESTINE AND PANCREAS}

The small intestine (SI) and its mucosa lose 20-30\% of their relative weight during the first $2 \mathrm{~d}$ PW while regeneration will need 5-10 d for full recovery [74] (Tab. II). Marked villus atrophy ( -45 to $-70 \%$ of preweaning values), particularly in the proximal SI, has been repeatedly reported during the degenerative phase [65, 74]. Intestinal crypt depth may [50,73] or may 
Table I. Weaning in young pigs: context, induced intestinal disorders and main risk factors.

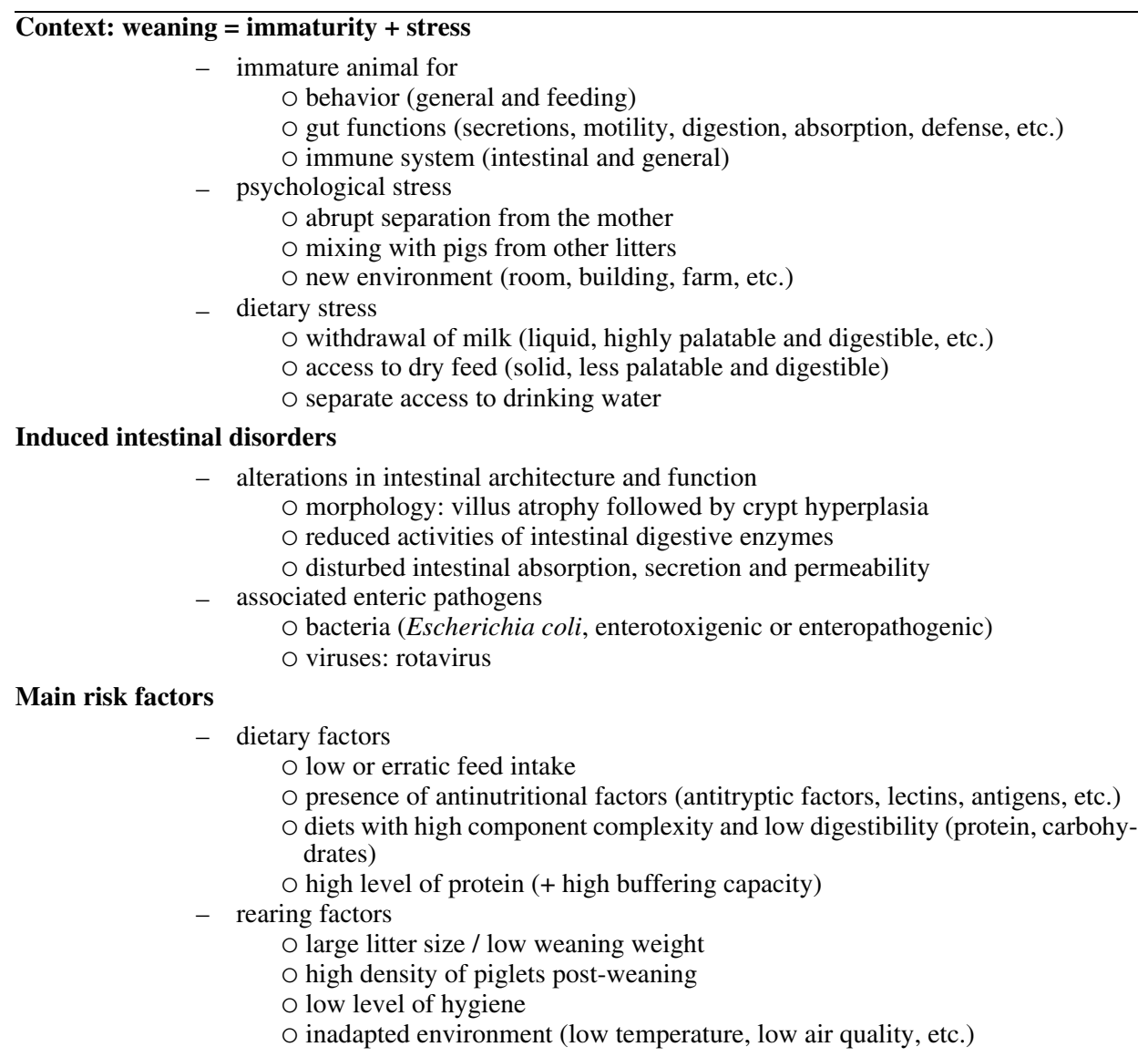

not $[33,83]$ be initially reduced. Intestinal crypt cell proliferation and rates of cell migration appear to depend strongly on energy availability during the first $2 \mathrm{~d}$ PW $[65,83]$. Crypt depth may also partly reflect gut pathogen exposure since it is shorter in segregated early weaners [78].

Reduced lactase activity, followed by increased maltase and sucrase activities during weaning, has been consistently reported [65] (Tab. II). This may reflect the maturation of intestinal function in relation to the weaning diet. It was recently shown that maltase mRNA expression developed in parallel with enzyme activity [41]. PW increase of intestinal peptidase activities appears more controversial [40] although recent results reported a transient depression in the activity of some peptidases [aminopeptidase $\mathrm{N}$ and dipeptidyl-peptidase IV [33]; amino-peptidases A and $\mathrm{N}$ and dipeptidyl-peptidase IV (J.P. Lallès et al. 2003, unpublished data)]. Finally, enteric infections after weaning further depress intestinal enzyme activities [55].

Regarding pancreatic function, immediate starvation or PW fasting lead to higher tissue enzyme concentrations [47, 48] (I. Luron 
Table II. Post-weaning changes in some architectural and functional parameters of the small intestine in young pigs weaned at 21 days of age (values in percentage of preweaning values) (INRA-UMRVP, unpublished data, 2003).

\begin{tabular}{|c|c|c|c|}
\hline & \multicolumn{3}{|c|}{ Time post-weaning (days) ${ }^{1}$} \\
\hline & +2 & +8 & +15 \\
\hline \multicolumn{4}{|l|}{ Small intestine } \\
\hline $\begin{array}{l}\text { - tissue weight } \\
\text { - mucosa weight }\end{array}$ & $\begin{array}{l}-18 \\
-30\end{array}$ & $\begin{array}{c}+14 \\
+5\end{array}$ & $\begin{array}{l}+49 \\
+36\end{array}$ \\
\hline \multicolumn{4}{|l|}{ Duodenum } \\
\hline $\begin{array}{l}\text { - villus height } \\
\text { - crypt depth } \\
\text { - digestive enzyme specific activities } \\
\text { - lactase } \\
\text { - maltase } \\
\text { - amino-peptidase N }\end{array}$ & $\begin{array}{l}-40 \\
-2 \\
-19 \\
-12 \\
-49\end{array}$ & $\begin{array}{c}-37 \\
+41 \\
\\
-71 \\
+2 \\
-39\end{array}$ & $\begin{array}{l}-23 \\
+43 \\
\\
-80 \\
+2 \\
-39\end{array}$ \\
\hline \multicolumn{4}{|l|}{ Pancreas } \\
\hline $\begin{array}{l}\text { - tissue weight } \\
\text { - trypsin activity } \\
\text { - amylase activity } \\
\text { - lipase activity }\end{array}$ & $\begin{array}{c}+2 \\
+27 \\
-8 \\
+35\end{array}$ & $\begin{array}{l}+23 \\
-6 \\
-7 \\
-59\end{array}$ & $\begin{array}{l}+57 \\
+65 \\
+23 \\
-61\end{array}$ \\
\hline
\end{tabular}

${ }^{1}$ Feed intake levels of 9,61 and $80 \mathrm{~g}$ per kg body weight ${ }^{0.75}$ per $\mathrm{d}$ at days 2,8 and 15 post-weaning, respectively.

et al., unpublished data) (Tab. II). This probably reflected a reduced secretion of pancreatic juice into the proximal SI lumen, as shown at a low feed intake [45]. Indeed, pancreatic secretion was shown to be $66 \%$ higher $1 \mathrm{~d}$ PW as compared to preweaning in piglets eating a substantial $(>20 \mathrm{~g})$ weaning diet while secretion remained depressed in low-eaters (I. Luron et al., unpublished data). Levels of pancreatic enzyme mRNA were low immediately PW suggesting a reduction in specific enzyme synthesis [48]. A few days later, tissue levels of mRNA and enzyme activities were progressively restored, with the exception of lipase activity. In pancreatic tissue and juice, trypsin, and to a lesser extent amylase activities are predominantly increased $\mathrm{PW}$, as an adaptative response to weaning feed [64]. Finally, transient depression in pancreatic secretion PW may contribute to intestinal tissue alterations since pancreatic duct liga- tion [4] and flow diversion [43] in rodents lead to villus atrophy in the proximal SI.

With respect to the age of weaning on subsequent intestinal architecture and function, recent data suggest that with very early weaning (at $7 \mathrm{~d}$ of age) both the extent and duration of structural changes are more pronounced, and the adaptation of pancreatic function is also slower, in comparison with weaning at $21 \mathrm{~d}$ of age [47, 48] (I. Luron et al., unpublished data). However, SI enzyme activities were depressed more after weaning at $21 \mathrm{~d}$. In another study, however, no consistent effect of weaning age was observed on villus/crypt architecture or specific activities of intestinal brush border and pancreatic enzymes [66]. Weaning at a later age ( 49 vs. 28 d) has limited effects on villus height, and no effect on crypt depth [84]. Similarly, pancreatic enzyme secretion appears to be independent of weaning age after $28 \mathrm{~d}$ [63]. 


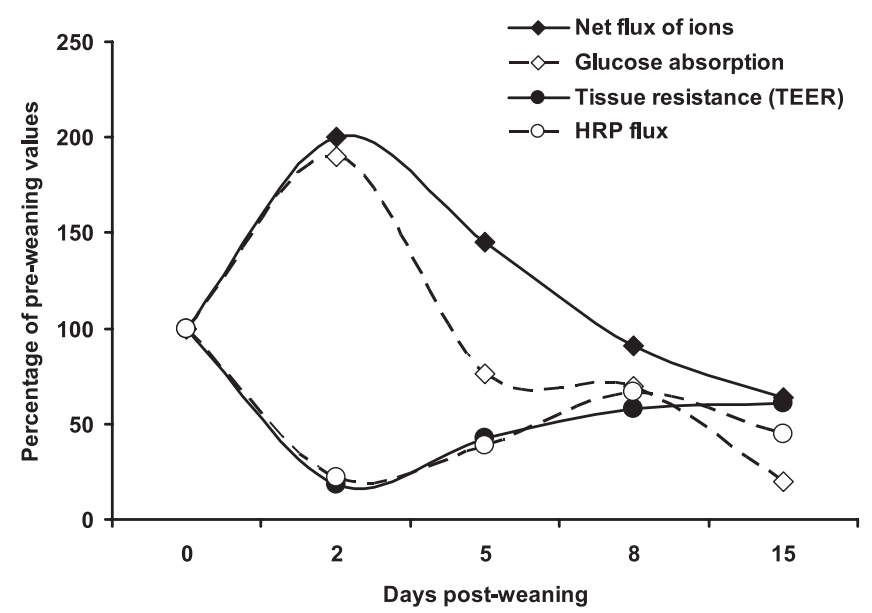

Figure 1. Influence of weaning on the net flux of ions, glucose absorption, tissue electrical resistance and horseradish peroxidase (HRP) flux in the proximal small intestine of young pigs weaned at 21 days of age. The values are expressed as a percentage of pre-weaning values (adapted from $[5,6])$.

\section{WEANING AND ABSORPTIVE, SECRETORY AND PERMEABILITY PROPERTIES OF THE SMALL INTESTINE}

The intestine displays various functions, including the absorption of nutrients, absorption and secretion of electrolytes (and water), secretion of mucin and immunoglobulins, and selective barrier protection against harmful antigens and pathogens. Comparisons between young sow-fed and fully-weaned piglets have been made for monosaccharide and amino acid transport $[10,68]$ but little is known on the impact of weaning on nutrient absorption during the immediate postweaning period. In one study using Ussing chambers, the carrier-mediated transport of the dipeptide Glycyl-L-Sarcosine did not change during the first $4 \mathrm{~d}$ PW [73]. Na+-dependent glucose absorption displayed a transient increase $2 \mathrm{~d} \mathrm{PW}$ in the proximal SI [6] (Fig. 1). This immediate PW period corresponded to fasting which we imposed experimentally in order to mimick the immediate PW anorexia often observed [50, 65]. Then a more chronic decrease of Na+-dependent glucose absorption in both proximal and distal SI was seen until d 15 [6].

Data on SI electrolyte and water absorption in vivo are scarce, the only study available indicating a transient decrease [56]. Net fluxes of electrolytes across the intestinal mucosa are measured as the tissue short-circuit current (Isc) in Ussing chambers. Basal Isc decreases with age in the proximal SI 2 wk PW as compared to $7 \mathrm{~d}$ old suckled piglets [30] and also in the distal SI of weaned pigs $7 \mathrm{~d}$ PW [54]. A more detailed analysis over time revealed a transient PW increase between $\mathrm{d} 2$ and $\mathrm{d} 5$ in basal Isc in the proximal SI but confirms the ileal Isc decrease [6]. This transient increase in basal Isc in the proximal SI may be explained, at least partly, by fasting [13] imposed experimentally PW in our studies [6]. In the colon, the basal Isc was shown to be higher $2 \mathrm{~d}$ PW than in $14 \mathrm{~d}$ unweaned piglets [3]. This was confirmed by our recent observations [6].

Enteric pathogens are known to stimulate intestinal secretion of electrolytes and 


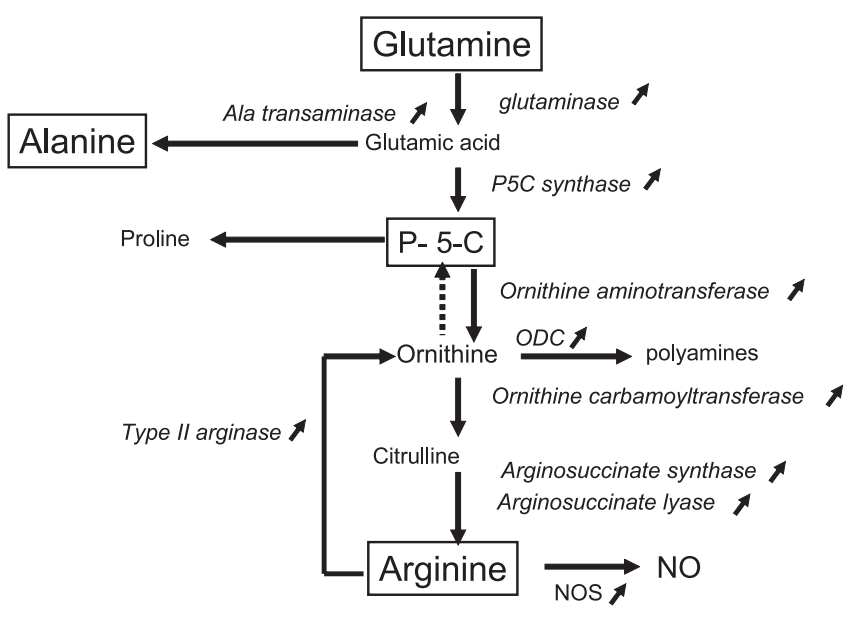

Figure 2. Main changes in the intestinal metabolism of amino acids in young pigs after weaning (N. Le FLoc'h, unpublished data). P-5-C: pyrroline-5-carboxylic acid, ODC: ornithine decarboxylase, NO: nitric oxide, NOS: NO synthase.

water. Indeed, this was shown to occur $4 \mathrm{~d}$ PW compared to the day of weaning, following intestinal loop infection with enterotoxigenic E. coli [56]. This may be accounted for by the peak in $E$. coli heat stable toxin binding capacity observed $3 \mathrm{~d}$ PW [53]. Bacterial toxin-induced electrolyte secretion involves 5-hydroxytryptamine (5-HT) and cyclic AMP. Thus toxin-mediated secretion can be evaluated in Ussing chambers using 5-HT and theophylline, a cAMP agonist. Proximal SI sensitivity to the secretagogues 5-HT and theophylline was reduced two-fold over the period of two weeks PW [6]. This confirms earlier work comparing young sow-fed to fully weaned pigs $[22,30]$. The colon of weaned pigs $2 \mathrm{~d}$ PW was shown in vitro to have increased responses to electrical field stimulation, thus involving the enteric nervous system, but not to 5-HT, carbachol (a Ca ${ }^{++}$agonist) or norepinephrine [3]. Collectively these data suggest an overall decrease in intestinal sensitivity to secretagogues over age with a transient hypersensitivity to toxins the first days PW.

Intestinal permeability comprises a passage of molecules between epithelial cells (also called para-cellular permeability) and through epithelial cells (also called transcellular permeability). This has most often been evaluated in vitro by measuring mucosal to serosal fluxes of small (mannitol, Na-fluoresceine isothiocyanate, FITC) or large (horseradish peroxidase, HRP) molecules, or tissue trans-epithelial electrical resistance (TEER) in Ussing chambers. TEER is considered to vary in an opposite manner to para-epithelial permeability. Earlier studies did not reveal any significant differences in para-cellular permeability between young sow-fed and fully weaned pigs [30]. However, detailed investigations recently reported increased para-cellular transport of mannitol [73] 2-4 d PW and decreased TEER [5] in the proximal jejunum (Fig. 1). However, in the mid-jejunum, no effect of weaning was observed on $\mathrm{Na}$ FITC mucosal-to-serosal fluxes [84]. Again, the effect of weaning on trans-cellular permeability to HRP seems to depend on the site of the jejunum studied since we observed a decrease of HRP flux after weaning in the proximal jejunum [5] (Fig. 2) whereas an increase has been recently reported 4 and 7 days PW in the 
Table III. Post-weaning changes in the tissular expression of cytokine genes in various intestinal sites of the gut of young pigs weaned at 28 days of age (adapted from [61]).

\begin{tabular}{lccccccc}
\hline Phase & & \multicolumn{7}{c}{ Cytokine gene $^{1}$} \\
\cline { 3 - 8 } PW $^{2}$ & Site $^{3}$ & IL-1 $\beta$ & IL-6 & TNF $\alpha$ & IL-8 & IL-12p40 & IL-18 \\
\hline $\mathrm{d} 0-\mathrm{d} 2$ & PSI & + & + & 0 & 0 & 0 & 0 \\
& MSI & + & + & + & 0 & 0 & 0 \\
& DSI & + & 0 & + & 0 & 0 & 0 \\
& PC & + & + & 0 & 0 & 0 & 0 \\
$\mathrm{~d} 5-\mathrm{d} 8$ & PSI & 0 & 0 & - & 0 & - & 0 \\
& MSI & 0 & 0 & 0 & - & 0 & - \\
& DSI & 0 & 0 & + & 0 & - & - \\
& PC & 0 & 0 & + & + & - & - \\
\hline
\end{tabular}

$1+$ : increase; -: decrease; 0 : no change (compared to pre-weaning values);

2 Phase post-weaning: major changes between day 0 and 2, and day 5 and 8 post-weaning;

3 PSI: proximal small intestine (SI), MSI: median SI, DSI: distal SI, PC: proximal colon.

mid-jejunum [84]. Curiously, at the ileum, earlier results led to conflicting results with either no change in TEER between $14 \mathrm{~d}$-old and 14 wk-old piglets [51] or an increase in TEER between newborn and $21 \mathrm{~d}$-old weanling piglets [72]. Colonic TEER increased $2 \mathrm{~d}$ PW [3]. Thus, further studies are warranted to clarify this question of changes in intestinal permeability PW. Finally, neither para- and trans-cellular transports nor fluid absorption changes $\mathrm{PW}$ were shown to be influenced by the age at weaning at 4 or 7 weeks [84].

\section{WEANING AND INTESTINAL CYTOKINES}

Intestinal alterations and PW diarrhea were initially thought to be a consequence of gut immune-mediated hypersensitivity reactions to dietary proteins $[17,37,76]$. Then an alternative hypothesis was formulated that the immediate PW anorexia was responsible for intestinal inflammation and that responses to new dietary antigens was probably secondary [50]. It was also shown that plasma IL-1 concentration transiently increased 2 d PW [49]. Recently, gene expression of the pro-inflammatory cytokines IL-1 $\beta$, IL-6 and TNF- $\alpha$ was shown to increase during the first $2 \mathrm{~d} \mathrm{PW}$, at the time when small intestinal villus height and digestive activities were drastically reduced [61] (Tab. III). Then gene expression returned to pre-weaning levels, except for TNF- $\alpha$ in the colon. IL-8 gene expression decreased in the jejunum and increased in the proximal colon after d $2 \mathrm{PW}$, without significant changes in the other gut segments. IL12p40 mRNA levels also decreased $2 \mathrm{~d} \mathrm{PW}$ in the duodenum, ileum and proximal colon. That was true for IL-18 in the jejunum only. The pro-inflammatory cytokines IL- $1 \beta$, IL- 6 and TNF- $\alpha$ are early mediators produced in response to tissue damage and are known to affect intestinal epithelial permeability and ion transport [52]. They could also be involved in the activation of intestinal epithelial cell differentiation and immune functions. IL-12 and IL-18 promote inflammatory responses by enhancing "type-1" lymphocyte and natural killer (NK) cell responses [58]. Thus weaning in piglets is associated with early gene up-regulation of pro-inflammatory cytokines probably contributing to early functional disorders favoring diarrhea. Subsequent down-regulation of most pro-inflammatory cytokine genes could be directly mediated by heat shock proteins [46]. 
Table IV. Post-weaning changes in the tissue levels of heat shock proteins (HSP) in various sites of the gut of young pigs weaned at 28 days of age (adapted from [16]).

\begin{tabular}{cccccc}
\hline & & \multicolumn{4}{c}{ Time post-weaning (hours) ${ }^{1}$} \\
\cline { 3 - 6 } HSP type & Site & 6 & 24 & 48 & $>72$ \\
\hline HSP 27 & Stomach & + & + & 0 & 0 \\
& Mid-jejunum & + & + & 0 & 0 \\
& Proximal colon & + & + & + & 0 \\
HSP 70 & Stomach & + & + & + & 0 \\
& Mid-jejunum & + & + & 0 & 0 \\
& Proximal colon & 0 & + & + & 0 \\
HSP 90 & Stomach & - & 0 & + & 0 \\
& Mid-jejunum & - & + & + & 0 \\
& Proximal colon & 0 & - & - & 0 \\
\hline
\end{tabular}

${ }^{1}+$ : increase; -: decrease; 0 : no change (compared to pre-weaning values).

\section{WEANING AND INTESTINAL CELL PROTECTION BY HEAT SHOCK PROTEINS}

Cells, tissues and organs subjected to various kinds of stress, including heat, become resistant to a second stress thanks to the production of so-called heat shock proteins (HSP). They belong to the families of low (HSP 27), medium (HSP 70) or high (HSP 90) molecular weight proteins with various cytoprotective functions (see review by [24]). HSP 27 interferes with actin filament dynamics of the cytoskeleton whereas HSP 70 confers thermotolerance and protects against apoptosis, endotoxins, reactive oxygen species, radiation and ischemia. HSP 90 is considered as a house-keeping protein for cell growth and differenciation. HSP are involved in mucosal defense as shown in stomach pathophysiological states [81]. Recently, HSP 25 and HSP 70 were demonstrated to be implicated in the protective actions of butyrate [70] and glutamine [88], respectively, in cultured cells. Since these nutrients are known to alleviate small intestine $\mathrm{PW}$ alterations in piglets, we studied the impact of weaning on gut HSP patterns [16]. Most changes observed in HSP protein concentrations were precocious (6 to $48 \mathrm{~h}$ PW) and transient (Tab. IV). HSP 27 and HSP 70 were over-expressed, especially in the stomach and proximal SI. In constrast, HSP 90 tissue levels increased in the stomach and jejunum while later decreasing in the duodenum, ileum, and colon. Part of these changes in HSP 90 expression may be explained by fasting [31]. Interestingly, the mechanisms of HSP response-induced cytoprotection involve inhibition of pro-inflammatory cytokine production and induction of epithelial cell proliferation [46].

\section{WEANING AND INTESTINAL MUCINS}

Mucin through mucus greatly contributes to the health of the gut through lubrication, physico-chemical protection and prevention of bacterial adhesion (review by [27]). Curiously, data on gut mucin biology in pigs are scarce and rather conflicting. Earlier results obtained in sow-fed piglets indicated increased goblet cell densities in SI villi and crypts over the first five weeks of life [19]. Also, acidic goblet cells have densities higher in the villi, and lower in crypts, than neutral cells [8]. Weaning induced an early drop, followed by an 
increase between $\mathrm{d} 3$ and $\mathrm{d} 15 \mathrm{PW}$, in goblet cell densities in the villi [20]. This pattern may have resulted from transient PW anorexia since underfeeding lowers the levels of mucin [44] and goblet cell densities in the villi [57]. This apparently did not influence the neutral to acidic goblet cell ratio in the villi but cells with sulfated mucins had densities increased in the crypts [8]. Recent data does not confirm such changes in small intestinal villus goblet cell densities or mucin sub-types in PW piglets [73]. In the colon, a transient decrease in goblet cell densities of the three types (neutral, acidic, acidic-sulfated) was observed in one study [9] but not in another [8]. A third study reported reduced levels of fucose and glucosamine and increased levels of sulfate in colonic mucins following weaning [82]. Studying mucins in the intestinal lumen may provide more information on gut stimulation. Weaning appears to increase mucin concentrations in the ileal digesta [60]. We recently developed an ELISA assay for porcine gut mucin in order to explore this aspect further [62]. Thus, the actual changes in goblet cell and mucin biology following weaning are unclear and they warrant further elucidation.

\section{WEANING AND PROTEIN AND AMINO ACID METABOLISM}

The weight of the gastrointestinal tract of the piglet increases three-fold (from 2 to $6 \%$ of bodyweight) between birth and two weeks PW (see review by [12]). Most of this increase is due to enterally ingested nutrients. Transient anorexia results in an overall decrease in SI protein and DNA mass, particularly in the proximal SI. During resumption of feed intake, the increase in SI weight exceeds that of bodyweight, indicating the priority of the intestinal tissues for growth [71]. Gut nutrient requirements are covered by both the enteral and arterial routes, the former being essential for sustaining normal proliferation and growth $[11,77]$.
The gut of piglets, as for many mammals, has been shown to be a major site for amino acid (AA) oxidation (Gln, Glu, Asp), net synthesis (Pro, Ala, Tyr, Arg, ornithine, citrulline) and utilization for protein synthesis (Thr, Lys, Phe, branched-chain AA, Met) (review by [12]). Some indispensable AA are also essential to intestinal protection and defense: threonine for mucin, cysteine for glutathione, tryptophan and histidine for 5-HT and histamine, methionine for polyamines, arginine for nitric oxide, etc. [12]. Weaning is followed by substantial changes in AA metabolism (Fig. 2). Enterocyte metabolism of glutamine, arginine and citrulline is increased in weaned, compared to unweaned piglets [89]. Moreover, it results in the induction of the activity of various intestinal enzymes involved in the metabolism of these AA [25]. This was shown not to be age- or dietdependent [18] but to be a non-specific adaptation process mediated by glucocorticoids [25, 26, 91, 92]. Collectively these metabolic adaptations observed at weaning converge towards the production of molecules having a physiological importance for intestinal adaptation, repair and protection under stressful conditions: glutathione [69], energetic compounds and polyamines [91], and nitric oxide [93]. Oral supplementation with glutamine [90] or glutamate [23] PW were shown to prevent intestinal mucosal atrophy. These favorable effects may be mediated through down-regulation of proinflammatory cytokines in the intestinal mucosa [14].

Protein synthesis rate after weaning is increased in the intestine while decreased in the muscle [71] and intestinal protein synthesis is little influenced by protein or tryptophan deficiency $[15,67]$. This protection of the gut from protein deficiency has been confirmed in piglets fed high energy levels [21]. In parallel, an increase in oxygen consumption per $\mathrm{kg}$ lean mass is found in pigs limited in protein intake compared with controls. This may be related to the fact that, at a similar protein to energy ratio, increasing fat content of the diet strongly stimulates 
protein synthesis in portal-drained viscera [67]. By contrast, recent data reported that AA provided luminally are a key factor required to reduce the expression of genes connected with intestinal proteolysis [1]. Mucosal protein synthesis can be increased by adding a colostrum extract to the diet [47]. Thus, the metabolism of digestive organs of young pigs is well suited for developmental and adaptative changes even in situations of severe undernutrition that occurs with early weaning. The next step would be to distinguish between metabolic activities associated with digestive versus immune functions.

\section{WEANING AND INTEGRATION OF GUT PATHO-PHYSIOLOGY DATA}

Most data collected during the PW period converge to indicate that feed intake, body growth and intestinal villus height correlate positively $[65,74]$. Interestingly, trans- and para-cellular transport correlated positively, and villus height negatively, with CD8+ T lymphocyte densities, thus linking inflammation to morphological and functional alterations during weaning [73]. However, intestinal morphology parameters did not correlate with permeability [73], suggesting distinct mechanisms operate. Also PW energy intake tends to correlate with villus height in the mid SI and with CD4+ to CD8+ cell density ratio [73]. Crypt depth has been found to correlate with crypt mitotic counts [33], and with HSP 90 expression [16] emphasizing the role of this HSP in cell division and differentiation. Recently, using linear regression, we analyzed in detail the relationships between morphology parameters and digestive enzyme specific activities during the acute (d 0-d 3) and adaptative (d 3-d 8) PW phases (J.P. Lallès, 2003, unpublished data). First, the proximal SI was the most affected by the changes. Second, villus height to crypt depth ratio correlated better than villus height alone to enzyme activities during the acute phase. Furthermore, still during the acute phase, this ratio was positively correlated with the specific activities of amino-peptidases (A and $\mathrm{N}$ ) and disaccharidases (lactase, maltase, sucrase), but not with alkaline phosphatase, an enzyme often considered as a morphology marker. Relationships were the strongest with aminopeptidase $\mathrm{N}$ and lactase (these positively auto-correlated), and to a lesser extent with amino-peptidase A, maltase and sucrase. In sharp contrast with this, during the adaptative phase relationships between morphology and enzyme activities all became virtually non-significant. These data would suggest that during the immediate PW phase, changes are strongly inter-related and may collectively reflect the shortage in luminal nutrient provision. Indeed, it has recently been shown that the lack of luminal AA favors intestinal proteolysis [1]. In contrast, the adaptative phase is characterized by distinct patterns of enzyme adaptation to the new diet and the environment leading to a more adult phenotype.

\section{WEANING AND ALTERATIONS IN GUT STRUCTURE AND FUNCTION: SOLUTIONS?}

Immediate anorexia PW is now largely recognized as a major aetiological factor in gut disorders in piglets $[65,74]$. Therefore, the factors stimulating PW feed intake should improve gut structure and function.

As expected, dairy products including skim milk powder and whey have favorable effects on feed intake, growth performance, feed efficiency and health in piglets, because of high digestibility of proteins and energy (see review by [79]). Providing weaner diets in a liquid form is also favorable for feed intake and health [7, 35]. Supplementing diets with animal proteins such as colostrum [42] or spray dried plasma (SDP, review by [85]) do have a positive influence on the various aspects of the intestine. For example, SDP incorporated at a level of up to $6 \%$ was repeatedly shown to 
Table V. Influence of some dietary factors on small intestinal morphology in young pigs following weaning.

\begin{tabular}{|c|c|c|}
\hline Factor & Effect $^{1}$ & Reference \\
\hline Feed intake (increased) & favorable & [65] \\
\hline \multicolumn{3}{|l|}{ Diet composition, type of ingredients } \\
\hline * high lactose to protein ratio & favorable $(\mathrm{t})$ & [74] \\
\hline * protein digestibility (milk vs. feather) & NS & [74] \\
\hline * protein hydrolysis (wheat gluten) & NS & [74] \\
\hline * protein hydrolysis (soybean) & NS & [74] \\
\hline * plasma protein & favorable $^{2}$ & [85] \\
\hline \multicolumn{3}{|l|}{ Amino acid supplementation } \\
\hline * glutamine & favorable & [90] \\
\hline * glutamine & NS & [74] \\
\hline$*$ arginine & favorable & [23] \\
\hline$*$ arginine & NS & [74] \\
\hline * ornithine & NS & [23] \\
\hline$*$ citrulline & NS & [23] \\
\hline
\end{tabular}

${ }^{1}$ t: tendency, NS: non significant;

2 mainly through an increase in voluntary feed intake.

stimulate growth performance $(+27 \%)$, mostly as a result of increased feed intake $(+25 \%)$ [85]. These changes were reduced, however, in the presence of ingredients of plant origin. Recently, SDP also proved to be protective during the first week PW when incorporated together with other nutrients into drinking water [75], with the incidence and severity of PW diarrhea and intestinal damage usually being reduced. In addition to the high palatability of SDP, these positive effects probably involve the anabolic activity of IGF-1 present in SDP, the immunoglobulin-independent glycoprotein-enhanced protection against $E$. coli and the specific protection brought about by plasma immunoglobulins [85]. Interestingly, plasma IGF-1 level was also increased following colostrum supplementation [42]. Recently, the protective effect of specific anti-E.coli immunoglobulins from SDP was demonstrated [59]. Also SDP reduces pro-inflammatory cytokine (IL-1 $1 \beta$, IL-6 and TNF- $\alpha$ ) gene expression in many tissues [80] and immune cell density in the intestinal mucosa of piglets [34]. These data collectively suggest an overall reduction of the level of immune activation PW. Some studies with SDP, however, did not show improved responses to $E$. coli challenge [86] or reported immune over-responses and increased intestinal damage following a lipopolysaccharide challenge [80].

Increasing the level of feed (energy) intake, however, does not always lead to improvements in intestinal architecture and function: there is no effect on either paracellular permeability of mannitol in conventionally weaned piglets [73], or on mRNA expression and activity of disaccharidases and mRNA expression of peptidases in early weaned piglets (J. Marion et al., unpublished data). Besides feed intake, feed composition of weaner diets appears to have no, or limited, effects on intestinal transient inflammation [50], permeability and absorptive-secretory parameters in Ussing chambers $[5,6,54$, 73] or goblet cell populations and types of mucins [20,73]. High lactose-low protein diets tends to reduce villus atrophy and paracellular permeability but hydrolyzing plant proteins or providing either glucose, lactose or starch has no comparative advantage [74] (Tab. V). Studies with unsaturated fatty 
acids, which are known to be beneficial in humans and rodents, are scarce in piglets [12].

In contrast to the limited improvements of intestinal health through manipulating dietary energy supply, particular AA have proven to be valuable (Tab. V). This may be due to the recent finding that when provided luminally AA reduce intestinal proteolysis [1]. Supplementation with glutamine $(1-4 \%)$ and glutamate $(6.5 \%)$ improves both intestinal architecture and feed efficiency during the first week PW to various degrees $[23,90]$. This is true for arginine $(0.93 \%)$ but not for citrulline $(0.94 \%)$ or ornithine $(0.90 \%)$ supplementation [23]. In contrast, cystine supplementation adversely affects gut mass [32]. Alanine and glycine were earlier demonstrated to stimulate the production of the so-called "antisecretory factor" in weaned piglets, to improve growth performance and to reduce the incidence of diarrhea (see review by [28]). This factor is low in plasma immediately PW (see review by [38]). Finally, polyamine supplementation has been shown to improve the intestinal integrity and growth performance in 10 d-old piglets [29] but apparently has detrimental effects in older piglets [23]. Further studies are needed to evaluate the dose efficacy of AA supplementation.

\section{CONCLUSIONS AND PERSPECTIVES}

Many factors interact at weaning to generate spatio-temporal changes in architecture and functions of the piglet intestine. Based on PW feed intake kinetics, these changes have been divided into an early acute (or degenerative) phase and an adaptative (regenerative) phase [65]. The most recent intestinal physiology data obtained both in vivo and in vitro fit well with this concept. Indeed, the acute phase includes early tissue atrophy and degradation (by stromelysin proteases, [50]), inflammation (cells, cytokines) and transient up-regulation of cyto-protection systems (HSP), together with consequences on intestinal barrier function. Subsequently most of these early events are down-regulated to allow the regenerative phase to occur. However, some parameters are durably set at PW adult-type levels, reflecting, therefore, intestinal maturation. Although the spatial co-ordination of this process is apparent from some studies, the temporal sequence of events and their control remains to be fully described.

Regarding the dietary management of PW disorders, feed (energy) intake undoubtedly exerts a major influence on initiating the process. During the regenerative phase, many important AA contribute to alleviate intestinal alterations by providing gut tissue with fuel and precursors for defense systems and also by limiting proteolysis. In contrast with this, the sources of digestible energy do not appear to be so critical at this phase.

Finally, the known importance of the gut flora in maintaining gut health, through diversity, stability, metabolites and crosstalk with the epithelium and the underlying immune system (review by [2]), means that improved PW gut protection may be achieved through more subtle manipulation of diet fermentation by the flora along the digestive tract (see review by [87]). This topic is examined in detail in the following review of this workshop [36].

\section{ACKNOWLEDGEMENTS}

The European Union is greatly acknowledged for financial support of the project HEALTHYPIGUT (contract No. QLK5-CT 200000522). The authors are solely responsible for this text which does not represent the opinion of the EC, and the EC is not responsible for the information delivered.

\section{REFERENCES}

[1] Adegoke O.A.J., McBurney M.I., Samuels S.E., Baracos V.E., Modulation of intestinal protein synthesis and protease mRNA by luminal and systemic nutrients, Am. J. Physiol. 284 (2003) G1017-G1026. 
[2] Akkermans A.D.L., Konstantinov S.R., Zhu W.Y., Favier C.F., Williams B.A., Postnatal development of the intestinal microbiota of the pig, in: Ball R.O. (Ed.), Proceedings of the 9th International Symposium on Digestive Physiology in Pigs, Banff, AB, Canada, 2003, pp. 49-56.

[3] Bach T.A., Carey H.V., Developmental changes in neurally mediated ion transport in piglet distal colon, Pediatr. Res. 36 (1994) 144-151.

[4] Balas D., Senegas-Balas F., Bertrand C., Frexinos J., Ribet A., Effects of pancreatic duct ligation on the hamster intestinal mucosa, Digestion 20 (1980) 157-167.

[5] Boudry G., Péron V., Lallès J.P., Sève B., Development of intestinal epithelial barrier function at weaning in piglets, in: Ball R.O. (Ed.), Proceedings of the 9th International Symposium on Digestive Physiology in Pigs, Banff, AB, Canada, 2003, pp. 195-197.

[6] Boudry G., Péron V., Lallès J.P., Sève B., Weaning induces transient and long-lasting modifications of secretory and absorptive physiology of piglet small intestine, in: Ball R.O. (Ed.), Proceedings of the 9th International Symposium on Digestive Physiology in Pigs, Banff, AB, Canada, 2003, pp. 121-123.

[7] Brooks P.H., Moran C.A., Beal J.D., Demeckova V., Campbell A., Liquid feeding for the young piglet, in: Varley M.A., Wiseman J. (Eds.), The weaner pig: nutrition and management, $\mathrm{CAB}$ International, Wallingford, UK, 2001, pp. 153178 .

[8] Brown P.J., Miller B.G., Stokes C.R., Blazquez N.B., Bourne F.J., Histochemistry of mucins of pig intestinal secretory epithelial cells before and after weaning, J. Comp. Pathol. 98 (1988) 313-323.

[9] Brunsgaard G., Morphological characteristics, epithelial cell proliferation, and crypt fission in cecum and colon growing pigs, Dig. Dis. Sci. 42 (1997) 2384-2393.

[10] Buddington R.K., Elnif J., Puchal-Gardiner A.A., Sangild P.T., Intestinal apical amino acid absorption during development of the pig, Am. J. Physiol. 280 (2001) R214-R247.

[11] Burrin D.G., Stoll B., Jiang R., Chang X., Hartmann B., Holst J.J., Greely G.H., Reeds P.J., Minimal enteral nutrient requirements for intestinal growth in neonatal piglets: how much is enough? Am. J. Clin. Nutr. 71 (2000) 1603-1610.

[12] Burrin D., Stoll B., Enhancing intestinal function to improve growth and efficiency, in: Ball R.O. (Ed.), Proceedings of the 9th International Symposium on Digestive Physiology in Pigs, Banff, AB, Canada, 2003, pp. 121-138.

[13] Carey H.V., Hayden U.L., Tucker K.E., Fasting alters basal and stimulated ion transport in piglet jejunum, Am. J. Physiol. 267 (1994) R156-R163.

[14] Coëffier M., Miralles-Barrachina O., Le Pessot F., Lalaude O., Daveau M., Lavoinne A., Lerebours E., Déchelotte P., Influence of glutamine on cytokine production by human gut in vitro, Cytokine 13 (2001) 148-154.

[15] Cortamira N.O., Sève B., Lebreton Y., Ganier P., Effects of dietary tryptophan on muscle, liver and whole-body protein synthesis in weaned piglets: relationship to plasma insulin, Brit. J. Nutr. 66 (1991) 423-435.

[16] David J.C., Grongnet J.F., Lallès J.P., Weaning affects the expression of heat shock proteins in different regions of the gastrointestinal tract of piglets, J. Nutr. 132 (2002) 25512561.

[17] Dréau D., Lallès J.P., Contribution to the study of gut hypersensitivity reactions to soyabean proteins in preruminant calves and early-weaned piglets, Livest. Prod. Sci. 60 (1999) 209-218.

[18] Dugan M.E.R., Knabe D.A., Wu G., The induction of citrulline synthesis from glutamine in enterocytes of weaned pigs is not due primarily to age or change in diet, J. Nutr. 125 (1995) 2388-2393.

[19] Dunsford B.R., Haensly W.E., Knabe D.A. Neutral and acidic goblet cell concentrations in the small intestine of the unweaned pig, Biol. Neonate 57 (1990) 194-199.

[20] Dunsford B.R., Haensly W.E., Knabe D.A., Effects of diet on acidic and neutral goblet cell populations in the small intestine of early weaned pigs, Am. J. Vet. Res. 52 (1991) 1743-1746.

[21] Ebner S., Schocknecht P., Reeds P., Burrin D. Growth and metabolism of gastrointestinal and skeletal muscle tissues in protein-malnourished neonatal pigs, Am. J. Physiol. 266 (1994) 1736-1743.

[22] Erlwanger K.H., Unmack M.A., Grondahl M.L., Skadhauge E., Thorboll J.E., Effect of age on vasoactive intestinal polypeptideinduced short-circuit current in porcine jejunum, Comp. Biochem. Physiol. A 124 (1999) 29-33.

[23] Ewtushick A.L., Bertolo R.F.P., Ball R.O., Intestinal development of early-weaned piglets receiving diets supplemented with selected amino acids or polyamines, Can. J. Anim. Sci. 80 (2000) 653-662.

[24] Feder M., Hofmann G.E., Heat shock proteins, molecular chaperones, and the stress response: evolutionary and ecological physiology, Ann. Rev. Physiol. 61 (1999) 243-282.

[25] Flynn N.E., Wu G., Glucocorticoids play an important role in mediating the enhanced metabolism of arginine and glutamine in enterocytes 
of postweaning pigs, J. Nutr. 127 (1997) 732_737.

[26] Flynn N.E., Meininger C.J., Kelly K., Ing N.H., Morris S.M., Wu G., Glucocorticoids mediate the enhanced expression of intestinal type II arginase and argininosuccinate lyase in postweaning pigs, J. Nutr. 129 (1999) 799_ 803.

[27] Forstner J.F., Forstner G.G., Gastrointestinal mucus, in: Johnson L.R. (Ed.), Physiology of the gastrointestinal tract, Raven Press, New York, USA, 1994, pp. 1255-1283.

[28] Goransson L., Alternatives to antibiotics The influence of new feeding strategies for pigs on biology and performance, in: Garnsworthy P.C., Wiseman J. (Eds.), Recent advances in animal nutrition, Nottingham University Press, UK, 1997, pp. 45-56.

[29] Grant A.L., Thomas J.W., King K.J., Liesman J.S., Effect of dietary amines on small intestine variables in neonatal pigs fed soy protein isolate, J. Anim. Sci. 68 (1990) 363-371.

[30] Grondahl M.L., Hansen M.B., Larsen I.E., Skadhauge E., Age and segmental differences in 5-hydroxytryptamine-induced hypersecretion in the pig small intestine, J. Comp. Physiol. B 166 (1996) 21-29.

[31] Grongnet J.F., David J.C., Reciprocal variations in nNOS and HSP90 are associated with fasting in gastrointestinal tract of the piglet, Dig. Dis. Sci. 48 (2003) 365-372.

[32] Harte R.D., Shoveller H.K., Bertolo R.F.P., Ball R.O., Cystine supplementation adversely affects small intestinal morphology, in: Ball R.O. (Ed.), Proceedings of the 9th International Symposium on Digestive Physiology in Pigs, Banff, AB, Canada, 2003, pp. 213-215.

[33] Hedemann M.S., Hojsgaard S., Jensen B.B. Small intestinal morphology and activity of intestinal peptidases in piglets around weaning, J. Anim. Physiol. A. Anim. Nutr. 87 (2003) 32-41.

[34] Jiang R., Chang X., Stoll B., Fan M.Z., Arthington J., Weaver E., Campbell X., Burrin D.G., Dietary plasma protein reduces small intestinal growth and lamina propria cell density in early weaned pigs, J. Nutr. 130 (2000) 21-26.

[35] Kim J.H., Heo K.N., Odle J., Han K., Harrell R.J., Liquid diets accelerate the growth of early-weaned pigs and the effects are maintained to market weight, J. Anim. Sci. 79 (2001) 427-434.

[36] Konstantinov S.R., Zhu W.Y., Favier C.F., Williams B.A., Klüss J., Souffrant W.B., Smidt H., Akkermans A.D.L., Gut function and dysfunction in young pigs: microbiology, Anim. Res. 53 (2004) in press.

[37] Lallès J.P., Salmon H., Effects of dietary antigens on health, performance and immune sys- tem of pigs at weaning, in: Souffrant W.B., Hagmeister H. (Eds.), VIth International Symposium on Digestive Physiology in Pigs, Bad-Doberan, Germany, EAAP Publication No. 80, Vol. 11, 1994, pp. 295-307.

[38] Lange S., Lonnroth I., The anti-secretory factor: synthesis, anatomical and cellular distribution, and biological action in experimental and clinical studies, Int. Rev. Cytol. 210 (2001) 39-75

[39] Le Dividich J., Sève B., Effects of underfeeding during the weaning period on growth, metabolism, and hormonal adjustements in the piglet, Dom. Anim. Endocrinol. 19 (2000) 63-74.

[40] Le Huërou-Luron I., Peiniau J., Guilloteau P., Aumaitre A., Are the activities of intestinal peptidases age- and diet-dependent in piglets? in: Lindberg J.E., Ogle B. (Eds.), Digestive physiology of pigs, CABI Publishing, Oxon, UK, 2001, pp. 20-22.

[41] Le Huërou-Luron I., Petersen Y.M., Hartmann B., Holst J.J., Sangild P.T., Exogenous GLP2 has only marginal effects on weaninginduced intestinal adaptation in piglets, in: Ball R.O. (Ed.), Proceedings of the 9th International Symposium on Digestive Physiology in Pigs, Banff, AB, Canada, 2003, pp. 164-166.

[42] Le Huërou-Luron I., Marion J., Bebin K., Thomas F., Ganier P., Thibault J.N., Le Dividich J., Supplementation of a weaning diet with a bovine colostrum extract minimises post-weaning duodenal structural, but not functional, alterations in 7-d-old piglets, in: Ball R.O. (Ed.), Proceedings of the 9th International Symposium on Digestive Physiology in Pigs, Banff, AB, Canada, 2003, pp. 238-240.

[43] Levi A.C., Borghi F., Petrino R., Bargoni A., Fronticelli C.M., Gentilli S., Modifications of the trophism of intestinal mucosa after intestinal and bilio-pancreatic diversion in the rat, Italian J. Gastroenterol. 23 (1991) 202-207.

[44] Lopez-Pedrosa J.M., Torres M.I., Fernandez M.I., Rios A., Gill A., Severe malnutrition alters lipid composition and fatty acid profile of the small intestine in newborn piglets, J. Nutr. 128 (1998) 224-233.

[45] Makkink C.A., Negulescu G.P., Guixin Q., Verstegen M.W.A., Effect of dietary protein source on feed intake, growth, pancreatic enzyme activities and jejunal morphology in newly-weaned piglets, Brit. J. Nutr. 72 (1994) 353-368.

[46] Malago J.J., Koninkx J.F.J.G., van Dijk J.E., The heat shock response and cytoprotection of the intestinal epithelium, Cell Stress Chaperones 7 (2002) 191-199.

[47] Marion J., Biernat M., Thomas F., Savary G., Lebreton Y., Zabielski R., Le Huërou-Luron I., Le Dividich J., Small intestine growth and 
morphometry in piglets weaned at 7 days of age, Effect of level of energy intake, Reprod. Nutr. Dev. 42 (2002) 339-354.

[48] Marion J., Romé V., Savary G., Thomas F., Le Dividich J., Le Huërou-Luron I., Weaning and feed intake alter pancreatic enzyme activities and corresponding mRNA levels in 7-d-old piglets, J. Nutr. 133 (2003) 362-368.

[49] McCracken B.A., Gaskins H.R., Ruwe-Kaiser P.J., Klasing K.C., Jewell D.E., Diet-dependent and diet-independent metabolic responses underlie growth stasis of pigs at weaning, J. Nutr. 125 (1995) 2838-2845.

[50] McCracken B.A., Spurlock M.E., Roos M.A., Zuckermann F.A., Gaskins H.R., Weaning anorexia may contribute to local inflammation in the piglet small intestine, J. Nutr. 129 (1999) 613-619.

[51] McEwan G.T., Schousboe B., Nielsen C.G., Skadhauge E., Effect of age on the secretory capacity of pig small intestine in vivo and in vitro, Am. J. Physiol. 259 (1990) G474-G480.

[52] McKay D.M., Baird A.W., Cytokine regulation of epithelial permeability and ion transport, Gut 44 (1999) 283-289.

[53] Mezoff A.G., Jhensen N.J., Cohen M.B., Mechanisms of increased susceptibility of immature and weaned pigs to Escherichia coli heat-stable enterotoxin, Pediatr. Res. 29 (1991) 424-428.

[54] Miller B.G., Skadhauge E., Effect of weaning in the pig on ileal ion transport measured in vitro, J. Vet. Med. A 44 (1997) 289-299.

[55] Mroz Z., Dekker R.A., Koopmans S.J., Le Huërou-Luron I., Performance, functional features of the digestive tract and haematological indices in weaned piglets fed antibioticfree diets and exposed to a viro-bacterial infection, in: Ball R.O. (Ed.), Proceedings of the 9th International Symposium on Digestive Physiology in Pigs, Banff, AB, Canada, 2003, pp. 180-182.

[56] Nabuurs M.J., Hoogendoorn A., van Zijderveldvan Bemmel A., Effect of supplementary feeding during the sucking period on net absorption from the small intestine of weaned pigs, Res. Vet. Sci. 61 (1996) 72-77.

[57] Nunez M.C., Bueno J.D., Ayudarte M.V.A.A., Rios A., Suarez M.D., Gil A., Dietary restriction induces biochemical and morphometric changes in small intestine of nursing piglets, J. Nutr. 126 (1996) 933-944.

[58] Okamura H., Kashiwamura S., Tsutsui H., Yoshimoto T., Nakanishi K., Regulation of interferon-gamma production by IL-12 and IL-18, Curr. Opin. Immunol. 10 (1998) 259264.

[59] Owusu-Asiedu A., Baidoo S.K., Nyachoti C.M., Marquardt R.R., Response of earlyweaned pigs to spray-dried porcine or animal plasma-based diets supplemented with eggyolk antibodies against enterotoxigenic Escherichia coli, J. Anim. Sci. 80 (2002) 2895-2903.

[60] Pestova M.I., Clift R.E., Vickers J.R., Franklin M.A., Mathew A.G., Effect of weaning and dietary galactose supplementation on digesta glycoproteins in pigs, J. Sci. Food Agric. 80 (2000) 1918-1924.

[61] Pié S., Lallès J.P., Oswald I., Influence of weaning on intestinal pro-inflammatory cytokine patterns in piglets, in: Ball R.O. (Ed.), Proceedings of the 9th International Symposium on Digestive Physiology in Pigs, Banff, AB, Canada, 2003, pp. 99-101.

[62] Piel C., Montagne L., Salgado P., Lallès J.P., Quantification of mucin in ileal digesta of piglets using a new Enzyme-Linked Immunosorbent Assay, in: Ball R.O. (Ed.), Proceedings of the 9th International Symposium on Digestive Physiology in Pigs, Banff, AB, Canada, 2003, pp. 134-136.

[63] Pierzynowski S.G., Westrom B.R., ErlansonAlbertsson C., Ahren B., Svendsen J., Karlsson B.W., Induction of exocrine pancreas maturation at weaning in young developing pigs, J. Pedriatr. Gastroenterol. Nutr.16 (1993) 287-293.

[64] Pierzynowski S.G., Westrom B.R., Svendsen J., Svendsen L., Karlsson B.W., Development and regulation of porcine pancreatic function, Int. J. Pancreatol. 18 (1995) 81-94.

[65] Pluske J.R., Hampson D.J., William I.H., Factors influencing the structure and function of the small intestine in the weaned pig: a review, Livest. Prod. Sci. 51 (1997) 215-236.

[66] Pluske J.R., Kerton D.J., Cranwell P.D., Campbell R.G., Mullan B.P., King R.H., Power G.N., Pierzynowski S.G., Westrom B., Rippe C., Peulen O., Dunshea F.R., Age, sex and weight at weaning influence organ weight and gastrointestinal development of weanling pigs, Aust. J. Agric. Res. 54 (2003) 515-527.

[67] Ponter A.A., Cortamira N.O., Sève B., Salter D.N., Morgan L.M., The effects of energy source and tryptophan on the rate of protein synthesis and on hormones of the entero-insular axis in the piglet, Brit. J. Nutr. 71 (1994) 661-674.

[68] Puchal A.A., Buddington R.K., Postnatal development of monosaccharides transport in pig intestine, Am. J. Physiol. 262 (1992) G895-G902.

[69] Reeds P.J., Burrin D.G., Stoll B., Jahoor F., Wykes L., Henry J., Frazer M.E., Enteral glutamate is the preferential source for mucosal glutathione synthesis in fed piglets, Am. J. Physiol. 273 (1997) E408-E415.

[70] Ren H., Musch M.W., Kojima K., Boone D., Ma A., Chang E.B., Short chain fatty acids induce intestinal epithelial heat shock protein 
25 in IEC18 cells, Gastroenterology 121 (2001) 631-639.

[71] Sève B., Reeds P.J., Fuller M.F., Cadenhead A., Hay S.M., Protein synthesis and retention in some tissues of the young pig as influenced by dietary protein intake after early-weaning. Possible connection to the energy metabolism, Reprod. Nutr. Dev. 26 (1986) 849-861.

[72] Smith C.D., Cardona M.A., Wishnev S.A., Kurkchubasche A.G., Rowe M.I., Unique characteristics of the neonatal mucosal barrier, J. Pediatr. Surg. 27 (1992) 333-338.

[73] Spreeuwenberg M.A.M., Verdonk J.M.A.J., Gaskins H.R., Verstegen M.W.A., Small intestine epithelial barrier function is compromised in pigs with low feed intake at weaning, J. Nutr. 131 (2001) 1520-1527.

[74] Spreeuwenberg M.A.M., Diet composition and gut integrity in weaned piglets, Ph.D. thesis, Wageningen University, Wageningen, The Netherlands, 2002.

[75] Steidinger M.U., Goodband R.D., Tokach M.D., Nelssen J.L., Dritz S.S., Borg B.S., Campbell J.M., Effects of providing a watersoluble globulin in drinking water and diet complexity on growth performance of weanling pigs, J. Anim. Sci. 80 (2002) 3065-3072.

[76] Stokes C.R., Miller B.G., Bailey M., Wilson A.D., Bourne F.J., The immune response to dietary antigens and its influence on disease susceptibility in farm animals, Vet. Immunol. Immunopathol. 17 (1987) 413-423.

[77] Stoll B., Chang X., Fan M.Z., Reeds P.J., Burrin D.G., Enteral nutrient intake level determines intestinal protein synthesis and accretion rates in neonatal pigs, Am. J. Physiol. 279 (2000) G288-G294.

[78] Tang M., Laarveld B., VanKessel A.G., Hamilton D.L., Estrada A., Patience J.F., Effect of segregated early weaning on postweaning small intestinal development in pigs, J. Anim. Sci. 77 (1999) 3191-3200.

[79] Thacker P.A., Nutritional requirements of early weaned pigs: a review, Pig News Info. 20 (1999) $13 \mathrm{~N}-24 \mathrm{~N}$.

[80] Touchette K.J., Carroll J.A., Allee G.L., Matteri R.L., Dyer C.J., Beausang L.A., Zannelli M.E., Effect of spray-dried plasma and lipopolysaccharide exposure on weaned pigs: I. Effects on the immune axis of weaned pigs, J. Anim. Sci. 80 (2002) 494-501.

[81] Tsukimi Y., Okabe S., Recent advances in gastrointestinal pathophysiology: role of heat shock proteins in mucosal defense and ulcer healing, Biol. Pharmacol. Bull. 24 (2001) 1-9.

[82] Turck D., Feste A.S., Lifschitz C.H., Age and diet affect the composition of porcine colonic mucins, Pediatr. Res. 33 (1993) 564-567.
[83] Van Beers-Schreurs H.M.G., Nabuurs M.J.A., Vellenga L., Kalsbeekvandervalk H.J., Wensing T., Breukink H.J., Weaning and the weanling diet influence the villous height and crypt depth in the small intestine of pigs and alter the concentrations of short-chain fatty acids in the large intestine and blood, J. Nutr. 128 (1998) 947-953.

[84] Van der Meulen J., Koopmans S.J., Dekker R.A., Hoogendoorn A., Weaning at 4 or 7 weeks: consequences for intestinal function and growth, in: Ball R.O. (Ed.), Proceedings of the 9th International Symposium on Digestive Physiology in Pigs, Banff, AB, Canada, 2003, pp. 140-142.

[85] Van Dijk A.J., Everts H., Nabuurs N.J.A., Margry R.J.C.F., Beynen A.C., Growth performance of weaned pigs fed spray-dried animal plasma: a review, Livest. Prod. Sci. 68 (2001) 263-274.

[86] Van Dijk A.J., Enthoven P.M.M., Van den Hoven S.G.C., Van Laarhoven M.M.M.H., Niewold T.A., Nabuurs M.J.A., Beynen A., The effect of dietary spray-dried porcine plasma on clinical response in weaned piglets challenged with a pathogenic Escherichia coli, Vet. Microbiol. 84 (2002) 207-218.

[87] Williams B.A., Verstegen M.W.A., Tamminga S., Fermentation in the large intestine of single-stomached animals and its relationship to animal health, Nutr. Res. Rev. 14 (2001) 207227.

[88] Wischmeyer P.E., Musch M.W., Madonna M.B., Thisted R., Chang E.R., Glutamine protects intestinal epithelial cells: role of inducible HSP70, Am. J. Physiol. 272 (1997) G879-G884.

[89] Wu G., Borbolla A.G., Knabe D.A., The uptake of glutamine and release of arginine, citrulline and proline by the small intestine of developing pigs, J. Nutr. 124 (1994) 2437 2444.

[90] Wu G., Meier S.A., Knabe D.A., Dietary glutamine supplementation prevents jejunal atrophy in weaned pigs, J. Nutr. 126 (1996) 2578-2584.

[91] Wu G., Flynn N.E., Knabe D.A., Jaeger L.A., A cortisol surge mediates the enhanced polyamine synthesis in porcine enterocytes during weaning, Am. J. Physiol. 279 (2000) R554-R559.

[92] Wu G., Meininger C.J., Kelly K., Watford M., Morris S.M., A cortisol surge mediates the enhanced expression of pig intestinal pyrroline-5-carboxylate synthase during weaning, J. Nutr. 130 (2000) 1914-1919.

[93] Wu G., Meininger C.J., Regulation of nitric oxide synthesis by dietary factors, Annu. Rev. Nutr. 22 (2002) 61-86. 